\title{
建筑工程中钻孔灌注桩后注浆施工技术的应用
}

杨艳红 于丹 徐学峰

中建二局第四建筑工程有限公司

DOI:10.32629/btr.v2i3.1954

[摘 要] 建筑行业作为国民经济持续增长的重要组成部分, 在城市基础设施建设力度不断增强下,建筑工程规模进一步扩大, 施工技术也变得愈加复杂。钻孔灌注桩后注浆施工技术在施工中应用,适用范围广, 可以有效提升梁柱承载力,获得可观的应用 效果。本文就建筑工程施工中应用钻孔灌注桩后注浆施工技术,应该明确技术应用要点,保证注浆质量,打造高质量的建筑工程 项目。

[关键词] 钻孔; 灌注桩后注浆; 混凝土建筑; 质量控制

当前建筑工程规模不断扩大, 城市土地资源十分紧张, 为了应对这一问题, 高层建筑和超高层建筑涌现, 所选择的 施工高技术愈加复杂。在高层建筑施工中, 钻孔灌注桩后注 浆施工技术应用, 主要是将灌注桩技术和土体加固技术整合 在一起, 可以改善传统技术桩侧泥皮和桩底沉渣问题, 提升 土地强度和桩柱承载力, 为工程结构稳定性和承载力提供坚 实保障。通过建筑工程中钻孔灌注桩后注浆施工技术应用研 究, 有助于推动技术不断改进和完善, 最大程度上控制施工 偏差, 为后续施工活动有序开展提供支持。

\section{1 钻孔灌注桩后注浆施工技术概述}

钻孔灌注桩后注浆施工技术在建筑工程施工中应用, 对 于工程整体质量影响较大。在建筑工程施工中, 不可避免的 出现泥皮、沉渣问题, 通过钻孔灌注桩后注浆施工技术有助 于规避此类问题, 提升桩整体承载力, 将桩基沉降量控制在 合理范围内。与此同时, 在建筑工程施工中钻孔灌注桩后注 浆施工技术应用具有一定可观性特点, 在满足施工技术要求 同时, 打造高品质工程项目, 提升建筑企业核心竞争优势 ${ }^{[1]}$ 。

\section{2 建筑工程钻孔灌注桩后注浆施工技术分析}

建筑工程施工中, 主要是在成孔后实施, 并且检查关键 预埋和混凝土养护情况。

\section{1 设置孔底注浆室}

在建筑工程灌注桩后注浆施工中, 孔底注浆室作为基础 部分, 施工过程中严格控制压浆管底部, 伸出钢筋笼 $15 \mathrm{~cm}$ 左 右, 需要依据施工规范和要求进行施工。

\section{2 设置注浆管}

桩身钢筋笼制作后, 需要严格检验质量, 钢筋笼设置镀 锌钢管材料制成的注浆管, 直径为 $\phi 2.5 \mathrm{~cm} \sim 3.5 \mathrm{~cm}$ 左右, 注 浆管下部增设出浆口, 在孔底 $30 \mathrm{~cm} \sim 50 \mathrm{~cm}$ 以上, 使用塑料膜 将出浆口包裹起来 ${ }^{[2]}$ 。结合地质条件和技术要求, 设置桩侧 注浆来提升注浆效果。结合注浆要求确定桩侧注浆位置, 设 置在桩底上 $8 \mathrm{~cm} \sim 12 \mathrm{~cm}$, 截面间距 $8 \mathrm{~cm}$ 左右, 并使用丝扣连接 压浆管。

$$
\begin{aligned}
& 2.3 \text { 固定注浆管 } \\
& \text { 注浆管位置设置是否合理, 直接关乎到灌注浆施工质 }
\end{aligned}
$$

量。从现实角度来分析, 施工期间将注浆管固定在钢筋笼上, 单项截流阀用于出浆口, 并在混凝土浇筑前进行压土操作。 此种方式优势较为突出, 可以最大程度上规避混凝土浆液流 入截流阀中, 保证灌注压力稳定, 提升注浆效率和质量。

2.4 混凝土灌注

在这个阶段, 将碎石置于灌注桩孔底, 然后进行混凝土 灌注施工, 并将灌注桩出浆口设置在碎石内, 提升混凝土灌 注质量, 为后续施工活动开展奠定基础 ${ }^{[3]}$ 。

\section{3 建筑工程中钻孔灌注桩后注浆施工技术应用路径}

3.1 优化注浆管制作

为了保证钻孔灌注桩后注浆施工质量, 应该做好前期的 注浆管制作工作, 具体结构包括三个部分。在端部花管制作 中, 可以通过梅花形方式制作出浆孔, 孔径为 $6 \mathrm{~cm} \sim 7 \mathrm{~cm}$, 直径 $25 \mathrm{~mm} \sim 30 \mathrm{~mm}$ 。在建筑工程施工中, 超长柱的制作需要严格控 制注浆管内部摩擦力, 可以选择 $\phi 30 \mathrm{~mm}$ 或 $\phi 38 \mathrm{~mm}$ 的钢管来 规避对自身压力的不良影响 ${ }^{[4]}$ 。注浆管制作中, 花管使用塑 料膜包裹, 并在外层使用铁丝绑扎。

3.2 安装和设置注浆管。注浆管安装中, 严格控制各个 注浆管对接精准性, 焊接风密封处理。注浆管安装和设置时, 遵循施工要求和规范进行, 保证注浆管安装连续性。

3.3 压水试验。灌注桩后注浆施工过程中, 压水试验作 为一项重要环节, 用于疏通灌注桩注浆通道, 提升注浆管可 灌性, 按照操作要求来检验管路是否通畅, 完全冲开表明覆 盖的一层水泥。

3.4 灌注桩注浆工艺。灌注桩后注浆施工过程中, 灌注 桩注浆质量高低对于整体质量影响较大, 要求施工前综合分 析可能影响灌注桩注浆质量的因素, 遵循施工技术规范进行 施工 ${ }^{[5]}$ 。

\section{4 建筑工程的灌注桩后注浆施工质量提升路径}

\section{1 加强钻孔质量控制}

钻孔是灌注桩后注浆的首要前提, 需要选择合理的钻孔 施工工艺, 根据钻孔施工规范标准和验收标准进行钻孔, 施 工人员灵活运用钻孔技术和设备, 提升钻孔施工质量。钻孔 阶段需要严格控制孔深、孔径和垂直度, 并对周边环境进行 
勘察, 了解桩端柱侧底层渗透性和地下水特性。

\section{2 控制注浆管和设备质量}

注浆管制作质量和设备质量高低, 对灌注桩后注浆质量 影响较大, 施工过程中主要是采用拌料机和高压注浆洜。注 浆管设备应用前, 检查注浆管和设备规格、型号和性能等因 素, 经过检验保证注浆管和设备质量符合施工要求。注浆管 和设备应用主要是起到辅助作用, 施工后检查注浆管牢固性 和注浆头密封性 ${ }^{[6]}$ 。随着钢筋笼下放时每节压浆管做好试水 试验活动, 如果发现水柱需要检查压浆管的丝扣连接和砂眼 密封情况。设置钢筋笼后, 对孔内残渣充分清理干净, 检查管 内水面, 并无异常及时封堵压浆管上口。

\section{3 控制混凝土浇筑质量}

混凝土作为建筑工程施工的主要材料, 用量大, 混凝土 注浆质量高低同灌注桩后注浆质量联系较为密切, 施工前需 要养检查注浆中泥浆密度和沉渣厚度, 并对灌量指数变化情 况实时监测, 混凝土充盈指数符合标准要求, 为灌注桩后注 浆整体质量提供保障。混凝土浇筑作为灌注桩后注浆施工中 重要环节, 需要现场管理人员重点监管和控制, 提升操作人 员的质量意识和责任意识, 规范化施工。同时, 确定注浆参数, 注浆压力结合涂层性质和注浆深度确定灌注浆压力, 土层压 力适宜在 $3 \mathrm{MPa} \sim 10 \mathrm{MPa}$, 饱和土层在 $1.2 \mathrm{MPa} \sim 4 \mathrm{MPa}$ 范围内。

4. 4 控制压水试验质量

压水试验是压浆前的一项重要工作, 在混凝土浇筑前 $3 \mathrm{~d} \sim 5 \mathrm{~d}$ 开塞, 保证混凝土强度符合开塞要求。压水试验检查 单向阀和管路畅通情况, 及时清理混凝土中的沉渣和泥浆, 在灌注桩成桩后 $24 \mathrm{~h}$ 后进行压水试验。需要注意的是, 桩侧 出现塌孔、扩孔问题, 则要求混凝土浇筑 $5 \mathrm{~h}$ 后压水试验, 可 以即时冲开较厚的混凝土覆盖层, 并做好试验记录, 便于后 续施工活动有序展开。

4.5 控制注浆施工过程

孔中的注浆量大小, 对于灌注桩后注浆施工质量和安全 影响较大, 压浆过程中保持慢速注浆, 先稀后浓, 避免压力突 然增大无法压浆, 或是顺着桩身上宫。压浆终止, 结合地质条 件来选择终止压浆时间, 如果卵石层和砾石密度较大, 可以
采用较大压浆压力进行施工, 通过注浆量大小来控制注浆质 量。桩侧的砂土层密度高, 以压浆压力和压浆量为主要指标, 注浆压力为 $8 \mathrm{MPa}$ 时终止注浆。与此同时, 在注浆施工过程中, 遵循设计规范要求来整合数据信息, 并做好注浆全过程质量 控制, 保证各项参数符合施工要求。

\section{6 注浆验收和养护}

灌注桩后注浆施工活动结束后, 需要及时验收施工质量, 并提交施工资料注浆施工 $20 \mathrm{~d}$ 后, 检验灌注桩承载力, 采用静 载试验方式确定单桩极限承载力。在灌注桩后注浆施工过程 中, 应该控制注浆管制作质量, 提供备用电源; 确定注浆时间 和注浆管养护工作, 记录注浆参数; 安排人员加强施工各个 环节质量检查, 分析工程整体性能是否符合需要; 所以施工 人员均要参与专业培训, 明确质量控制重要性, 提升专业能 力, 熟练运用钻孔灌注桩后注浆施工技术, 提升建筑工程施 工质量。

\section{5 结束语}

综上所述, 建筑工程涉及到众多内容, 钻孔灌注桩后注 浆施工技术功能性较强, 实际应用中应该做好前期勘察, 结 合工艺参数来提升单桩承载力和土体强度, 提升灌注桩后注 浆施工质量, 保证建筑工程灌注桩牢固稳定, 缩短工期同时, 打造高质量工程项目。

\section{[参考文献]}

[1]朱泽良.建筑工程中钻孔灌注桩后注浆施工技术的 应用[J].工程技术研究,2018,15(14):236-237。

[2]廖川国.建筑工程中灌注桩后注浆的施工技术研究 [J].建材与装饰,2018,21(32):14-15.

[3]龚俊.关于房屋建筑工程中钻孔灌注桩桩底注浆施工 技术的实践应用[J].现代物业(中旬刊),2018,19(07):208.

[4]王旭辉.建筑工程施工中灌注桩后注浆施工技术的应 用[J].建材与装饰,2018,22(25):49.

[5]郭长君.浅析灌注桩后注浆施工技术在建筑工程施工 中的应用[J].绿色环保建材,2018,31(06):171+173.

[6]杨峰.某建筑工程中灌注桩后注浆的施工技术要点初 探[J].江西建材,2018,11(03):56+60. 